\title{
A critical review of Integrating Ubunifu, informal science, and community innovations in science classrooms in East Africa
}

\author{
Peter C. Samuels ${ }^{1}$
}

Received: 20 November 2018 / Accepted: 11 March 2019 / Published online: 6 June 2019 (c) The Author(s) 2019

\begin{abstract}
This paper provides a brief critical review of the English executive summary to Integrating Ubunifu, informal science, and community innovations in science classrooms in East Africa (Semali et al. in Cult Stud Sci Educ 10:865-889, 2015. https://doi.org/10.1007/ s11422-014-9640-x). It was written as an example of a critical review for an Erasmus +-funded training (http://ec.europa.eu/programmes/erasmus-plus/) in Research Methods for Ph.D. students at the African Centre of Excellence for Innovative Teaching and Learning Mathematics and Science in Rwanda (http://aceitlms.ur.ac.rw/) in October 2018.
\end{abstract}

Keywords Indigenous innovations · Informal science $\cdot$ Ubunifu · iSPACES · Critical review

This executive summary provides an overview of a discussion paper based on a primary research study on Integrating Ubunifu, informal science, and community innovations in science classrooms in East Africa. It is situated within the context of endeavours to make science education more authentic in an African context. The study investigates current progress with the implementation of iSPACES (Semali and Mehta 2012) — a Tanzanian science education reform programme which draws from a systems-thinking approach and a holistic framework to science education (Shizha 2006). Although not mentioned in the executive summary, the acknowledgements of the main paper (Semali, Hristova and Owini 2015) state that iSPACES was, at the time of publication, only an experimental programme. The authors, Ladisalas Semali, Adelina Hristova, and Sylvia Owiny, were seeking to implement this programme in an integrated way rather than as an additional subject.

Lead Editor: Alejandro J. Gallard M.

This is a critical review of the English Executive Summary to Semali, L. M., Hristova, A., \& Owiny, S. A. (2015). Integrating Ubunifu, informal science, and community innovations in science classrooms in East Africa.

Peter C. Samuels

peter.samuels@bcu.ac.uk

1 Business School, Birmingham City University, Curzon Building, 4 Cardigan Street, Birmingham B4 7BD, UK 
Semali et al. found that iSPACES was often disrupted by in-service teachers' poor attendance and that indigenous innovations are not valued by parents. Their finding led them to discuss the absence of any serious attempt among educators and scholars to resolve indigenous children's disconnect in science classrooms and to address the question of what stakeholders can do to assist schools' promotion of integrated, formalized Western science education that allows inclusion of values and practical knowledge learned through students' cultural heritage, environments, and family settings.

The authors present a clear and persuasive argument in the opening paragraphs about the impetus for the reform programme, the integration of African cultural heritage in the science classroom, and the potential danger of excluding students' prior knowledge potentially leading to rote learning. It contains a valid critique of the lack of attention to indigenous knowledge concepts and African epistemologies in locally produced textbooks. In particular, the example provided for culturally inappropriate irrigation education certainly requires addressing. However, a serious weakness of this paper is its lack of any detail about its primary data analysis. This is at odds with the detailed analysis provided in the previous study (Semali and Mehta 2012) that introduced the iSPACES programme and which used a separate data collection process. This lack of detailed analysis raises the question of how far the research undertaken has actually moved forward the authors' assumed aspirations to provide academic evidence to persuade key stakeholders to adopt a culturally valid science curriculum more widely.

In addition, a number of the claims made in the discussion are disputable. The authors' claim that a failure to resolve the conflict between subject knowledge and reallife experience may ultimately lead to academic failure is disputed by many studies which have found that students from developing nations have a greater interest in science than those from developed nations (e.g. Awan, Sarwar, Naz and Norreen 2011). The lack of indigenous science role models for students in developing nations (Shiao 2018) may cause them only to aspire become like people from developed nations from whence they perceive science to have originated. This may itself partly be motivated by a general desire for wealth, as noted by Potvin and Hasni (2014), "strong schooling (in particular [science and technology] schooling) is often perceived as a good way to be spared from poverty (whether or not this is true)" (p. 100). The authors' use of the word "abysmal" (p. 868) when describing the inconsistency between community innovations and academic subjects therefore appears to be rather strident, perhaps being derived from idealistic rather than pragmatic concerns (Berliner 2008).

I cannot help questioning whether the authors are evaluating their own programme in an unbiased way. The reasons for in-service teachers' poor attendance of training events are not explored. One explanation might be that they did not believe sufficiently in the project. The style of the training provided may therefore require evaluation. The lack of valuing of indigenous innovations by parents suggests that they may be another stakeholder not buying into the reform programme. Perhaps the authors need to reflect more upon their own identity and role in their aspirational reform movement. In summary, the paper leaves me wondering how the authors can publish such a long, detailed discussion without providing a systematic literature review or proper primary data analysis and hope to move their own agenda forward.

Open Access This article is distributed under the terms of the Creative Commons Attribution 4.0 International License (http://creativecommons.org/licenses/by/4.0/), which permits unrestricted use, distribution, 
and reproduction in any medium, provided you give appropriate credit to the original author(s) and the source, provide a link to the Creative Commons license, and indicate if changes were made.

\section{References}

Awan, R. U. N., Sarwar, M., Naz, A., \& Noreen, G. (2011). Attitudes toward science among school students of different nations: A review study. Journal of College Teaching and Learning, 8(2), 43-50. https:// doi.org/10.19030/tlc.v8i2.3555.

Berliner, D. C. (2008). Research, policy, and practice: The great disconnect. In S. D. Lapan \& M. T. Quartaroli (Eds.), Research essentials: An introduction to designs and practices (pp. 295-326). San Francisco, CA: Jossey-Bass.

Potvin, P., \& Hasni, A. (2014). Interest, motivation and attitude towards science and technology at K-12 levels: A systematic review of 12 years of educational research. Studies in Science Education, 50(1), 85-129. https://doi.org/10.1080/03057267.2014.881626.

Semali, L. M., Hristova, A., \& Owiny, S. A. (2015). Integrating Ubunifu, informal science, and community innovations in science classrooms in East Africa. Cultural Studies of Science Education, 10, 865-889. https://doi.org/10.1007/s11422-014-9640-x.

Semali, L., \& Mehta, K. (2012). Science education in Tanzania: Challenges and policy responses. International Journal of Educational Research, 53, 225-239. https://doi.org/10.1016/j.ijer.2012.03.012.

Shiao, E. L. (2018). Developing scientists in developing countries. Retrieved from https://www.lindau-nobel .org/de/blog-developing-scientists-in-developing-countries/. Accessed 1 April 2019.

Shizha, E. (2006). Legitimizing indigenous knowledge in Zimbabwe: A theoretical analysis of postcolonial school knowledge and its colonial legacy. Journal of Contemporary Issues in Education, 1(1), 20-35. https://doi.org/10.20355/C5RP4J.

Publisher's Note Springer Nature remains neutral with regard to jurisdictional claims in published maps and institutional affiliations.

Peter C. Samuels is a Senior Lecturer in Research Practice in the Business School at Birmingham City University, UK. He teaches research methods to dissertation and doctoral students. His research interests include advanced mathematical thinking, academic writing education, and applied statistics education. He leads an Erasmus+ project for his University in partnership with two African Centres of Excellence based at the University of Rwanda. 